\title{
Identificadores de los judaizantes y la resignificación de sus rituales en el contexto novohispano
}

\author{
Silvia Hamui Sutton \\ silviahamui@hotmail.com \\ Universidad Iberoamericana (México)
}

\begin{abstract}
Resumen
La finalidad de este trabajo es exponer la problemática con la que se enfrentaron los criptojudíos al interpretar la "Ley de Moisés". Ante el miedo que provocaba la censura inquisitorial y el desconocimiento de su propia fe, se observa el desgaste y la transformación de la religión oficial judía, de la cual quedaron sólo rasgos aislados de los rituales sagrados ancestrales, pero resignificados para los conversos de la Nueva España. Además, se muestra cómo estos símbolos mutilados servían como fuente de conocimiento para los judaizantes, y también como identificadores usados por los delatores para inculparlos ante los tribunales inquisitoriales. El resultado fue un sincretismo que devino en el empobrecimiento de su judaísmo y la asimilación mal entendida del cristianismo.
\end{abstract}

Palabras clave: criptojudíos, Inquisición, Nueva España, siglo XVII, sincretismo.

\begin{abstract}
The objective of the article is to expound the problem that Crypto-Jews faced in interpreting the "Law of Moses". The fear provoked by the inquisitional censure and the lack of knowledge of their own faith caused the deterioration and transformation of the official religion, leaving only isolated elements of the sacred ancestral rituals that would gain new meanings for the converts of New Spain. Furthermore, it is showed how these mutilated symbols served as source of knowledge for Judaizers as well as identifying features used by informers in order to accuse them in front of inquisitorial courts. The result was a syncretism that caused the impoverishment of their Judaism and the misunderstood assimilation of Christianity.
\end{abstract}

Key words: Crypto-Jews, Inquisition, New Spain, $17^{\text {th }}$ Century, syncretism. 


\section{FRONTERAS}

de la historia

Los hispano-hebreos, establecidos en la península ibérica desde el siglo I, atravesaron por períodos alternados de paz y violencia hasta finales del siglo $\mathrm{XV}$, cuando se lanzó el edicto de expulsión, en $1492^{1}$. Cuando los árabes invadieron la península, en el $711 \mathrm{~d}$. C., los judíos experimentaron una época de libertad condicionada, ya que los musulmanes respetaron sus prácticas religiosas y sus costumbres, incluso confiaron en ellos para la defensa de las ciudades recién conquistadas (Sevilla, Granada, Toledo, etc.). La época del califato representó para los judíos un espacio de tranquilidad que propició el desarrollo cultural de sus comunidades y el posicionamiento del poder al lado de los gobernantes.

Sin embargo, cuando terminó el período del califato a causa de las guerras civiles, se produjo la primera gran matanza de los judíos en Granada. Poco después, con los almorávides y almohades, que enfatizaron su integración religiosa, se intensificó la persecusión de manera sistemática, por lo cual los judíos tuvieron que emigrar a los países cristianos. En ellos, los monarcas de cada lugar favorecieron los asentamientos judíos y concedieron privilegios a las aljamas y juderías. Sin embargo, desde el siglo XIII, la hostilidad popular fue creciendo hasta culminar en aterradoras matanzas a finales del XIV, que volvieron a propiciar, una vez más, el éxodo de los judíos, ahora hacia el norte de África y otros lugares mediterráneos.

Las comunidades hispano-hebreas se diezmaron: unos cedieron al bautizo forzoso, mientras otros simularon ser cristianos en la apariencia, pero practicando sus rituales en la intimidad. Los que quedaron en la península se trasladaron a las zonas rurales o a ciudades pequeñas, dispuestos a reconstruir lo perdido. La desigualdad religiosa propició el abuso del poder de los eclesiásticos y gobernantes, que sometían a las comunidades alternativas y minoritarias; empezó a germinar la idea de desconfiar y poner a prueba a los falsos conversos mediante la intervención del Tribunal de la Inquisición. La consecuencia inmediata fue la desaparición de la tolerancia, tanto para los judíos como para los musulmanes que formaban parte del reino.

Al subir al trono los Reyes Católicos, la situación heredada cargaba con vicios y aciertos arrastrados desde la Edad Media: la fe cristiana interactuaba con las decisiones políticas, es decir, había una identificación inseparable entre política

\footnotetext{
${ }^{1}$ Se supone que los primeros judíos que se asentaron, alrededor del siglo primero de nuestra era, en tierras hispánicas provenían de Tierra Santa. Al principio, se concentraron en costas como Tarragona y Tortosa; poco a poco fueron internándose en el territorio formando comunidades importantes en diferentes ciudades de la Península. Ya, en el siglo IV es indiscutible su presencia.
} 
y religión. Los gobernantes determinaron que atentar contra el catolicismo era considerado herejía y sacrilegio, considerados crímenes inminentes, por lo que requerían intervención jurídica del Estado. Así, censuraron de tajo la existencia de la alternancia.

La Inquisición fue creada para castigar y extirpar los núcleos de judaizantes para garantizar la unidad de creencias y prácticas cristianas, la Inquisición no tardó en asumir la empresa de vigilar y corregir los posibles "errores" de los "cristianos viejos"; de esta manera, el Santo Oficio dedicó muchos esfuerzos en procurar eliminar cualquier riesgo de práctica religiosa "extravagante". A grandes rasgos, los tipos de delito que el tribunal inquisitorial persiguió eran los siguientes: judaísmo, mahometismo, protestantismo, secta de alumbrados, proposiciones y blasfemias, superstición, bigamia, solicitación en confesión y delitos contra el Santo Oficio. (Sarrión 23-24).

Los Reyes Católicos lanzaron el edicto irrevocable de expulsión el 31 de marzo de 1492. Las alternativas entre las que los hispano-hebreos se vieron forzados a elegir eran el exilio o la conversión al cristianismo. Así, algunos optaron por abandonar su país en busca de libertad de credo; otros, anular sin cuestionamientos su religión, Sin embargo, un tercer grupo decidió aferrarse a sus creencias judías, pero aparentando prácticas ajenas.

La mayor parte de los exiliados vivió una etapa de búsqueda donde establecerse. Los de Castilla se trasladaron a Portugal, que les permitó su estancia durante ocho meses a cambio de una cuota. Los de Andalucía, prefirieron el norte de África, que estaba bajo el dominio del imperio turco otomano y fue donde encontraron circunstancias más favorables para su asentamiento; en general, los judíos que salieron por el norte y este de la península se esparcieron por toda Europa, algunos territorios también conquistados por el imperio turco otomano:

Durante los siglos XV al XVII, todas las provincias del Imperio Otomano a lo largo del Mediterráneo y del Mar Negro quedaron salpicadas de comunidades sefaradíes. Entre ellas sobresalieron [...] Constantinopla, Esmirna, Adrianópolis, Salónica y Safed, como sedes tanto de una vida económica pujante como de una erudición floreciente (misticismo de Safed). (Bel 34).

Las comunidades judías en Italia más relevantes estaban en Sicilia, Cerdeña y Nápoles, pero tuvieron la misma suerte que en la península, pues también fueron víctimas de la Inquisición. En Ferrara, Venecia y Liorna, en cambio, se formaron centros de estudio reconocidos y un gran auge literario tuvo lugar en los siglos posteriores. Los judíos que se expandieron más allá de los Alpes y los 


\section{FRONTERAS}

de la historia

Pirineos se asentaron en Burdeos, Toulouse, Lyon, Nantes, Ruan, el puerto flamenco de Amberes y Ámsterdam, que fue el escenario del florecimiento de una literatura religioso-intelectual durante los siglos XVII y XVIII; Londres, Hamburgo, Copenhague y hasta Viena fueron también centros de asentamiento. Incluso, algunos judíos expulsados de España optaron por abrirse fronteras en América, y se establecieron en las colonias de España, Portugal, Holanda, Francia e Inglaterra, arriesgándose al devenir de los descubridores.

Así, ante la circunstancia de persecución y expulsión de la península, el Nuevo Mundo se abrió como una posibilidad de vida; no obstante, se importaron los lineamientos inquisitoriales a las colonias americanas. Desde el siglo XVI, había criptojudíos en ciudades de América del Sur, que mantenían contacto con los conversos de la península y con otros judíos asentados en las diferentes diásporas. En colonias no hispánicas, los colonizadores querían poblar sus nuevos territorios americanos, por lo que ofrecieron facilidades para que se establecieran en ellos. Tal fue el caso de Pernambuco, colonia holandesa que en 1630 impulsó el primer asentamiento judío en el continente americano. En 1637 se estableció otro en Recife y luego en Mauricia, los cuales se unieron en 1649 pero desaparecieron en 1654, pues con la ocupación portuguesa se vieron forzados a regresar a Ámsterdam. Otros optaron por establecerse en Nueva Amsterdam, que años después se llamó Nueva York, pero sólo hasta 1740, con la llegada de un mayor número de judíos, se consolidó una comunidad formal, esencialmente sefaradí. En la zona del Caribe, tanto ingleses como holandeses se interesaron en colonizadores portugueses y españoles, pues tenían el idioma para convivir con los "cristianos nuevos" del Nuevo Mundo. En Curazao se formó la comunidad judía en 1659 con la llegada de 70 sefaradíes de Amsterdam. En las Antillas holandesas, igualmente, se estableció un lugar de rezo que servía a la congregación.

Las posibilidades de comenzar una nueva vida en esa región que parecía ofrecer ventajosas posibilidades económicas atrajo a centenares de inmigrantes judíos, casi todos ellos sefaradíes de Amsterdam, y a no pocos "cristianos nuevos" de diferentes regiones del Brasil, tanto de las partes conquistadas por los holandeses como también de los territorios ocupados por Portugal. (Kaplan 77).

La Nueva España, y Latinoamérica en general, atrajo un número considerable de cristianos nuevos que deseaban vivir como católicos, motivados a negar su origen judío y olvidar su impureza de sangre. Había también judíos que, esperanzados en evadir las persecusiones, por la distancia con la península y la dispersión territorial, querían mantener su religión. Debido a que se prohibía la 
entrada a personas que no fueran católicas, es decir, conversos con sus descendientes, así como a los portugueses, se propagaron las licencias falsas para que ingresaran en secreto moros y judíos a las colonias hispánicas.

En los primeros años del siglo XVI hubo una importante oleada de inmigrantes ${ }^{2}$; sin embargo, flotaba para los extranjeros la amenaza de las prohibiciones que estipulaban castigos severos ${ }^{3}$. Al principio, los inmigrantes que se establecieron en el nuevo continente gozaban de cierta tolerancia que motivó a familiares y correligionarios europeos a sumarse a los ya asentados en el territorio. Sin embargo, para 1573, con Felipe II, las leyes se hicieron más estrictas, y se fundó de manera estable el tribunal del Santo Oficio, que perseguía a los cristanos nuevos o criptojudíos, es decir, a aquéllos cuyos orígenes eran judíos o practicaban sus rituales en secreto.

Vivía este converso en constante zozobra, deseaba volver a su religión y esperaba constantemente un milagro. Su vida estaba llena de angustia y temía ser descubierto por llevar aún los ritos de su antigua fe, y sentía un gran temor a Dios por estar pecando en su ley y ser cristiano en las apariencias. (Gojman 73)

De esta manera, la identidad de los criptojudíos en la Nueva España estaba trasfigurada desde que salieron de la península. Sin embargo, como reacción necesaria frente al rechazo que impuso la Inquisición, se definieron actitudes en torno al judaísmo de acuerdo con las opciones limitadas que ofrecían las circunstancias. El comportamiento dual ambivalente entre ser judío, ser católico o ambos, creó un ambiente de sospechas y desprecios entre los cristianos "viejos", que se posicionaron en un nivel superior a partir de la dicotomía establecida por los monarcas, pues adquirieron mayor poder y autoridad ante quines no cumplían con los estatutos impuestos. La diferenciación entre los "aceptados" y los "rechazados" marcó pautas de comportamiento en las que se defendía un constructo de "verdad" que denigraba a un grupo para refrendar la

\footnotetext{
${ }^{2}$ Durante el reinado de Carlos V (1516- 1556) se fomentó la emigración hacia las colonias del Nuevo Mundo, tanto para poblar el territorio, como para motivar el comercio.

${ }^{3}$ El emperador Carlos V y el príncipe en sus Ordenanzas, dictaron una Cédula en Valladolid el 15 de septiembre de 1522, en la que se prohibía pasar a las Indias a los judíos recién convertidos, "y estas disposiciones se incluyeron en la Recopilación de Leyes de Indias [...]: ninguno nuevamente convertido a nuestra Santa Fe Católica de moro o judío, ni sus hijos pueden pasar a la Indias sin expresa licencia nuestra". La Ley 24 título V, libro VII dicta: "Con grandes diligencias inquieran y procuren saber los virreyes, audiencias, gobernadores, que esclavos o esclavas berberiscos o libres nuevamente convertidos de moros e hijos de judíos, residen en las Indias y en cualquier parte y echen de ellas a los que hallaren, enviándolos a estos reinos en los primeros navíos que vengan y en ningún caso queden en aquellas provincias". Ver Gojman 67-68.
} 


\section{FRONTERAS}

de la fistoria

Vol.12 / 2007

perspectiva del otro. Las posibilidades de subsistencia de las comunidades judías hispánicas se anularon, con lo cual se desmembró la trayectoria cultural milenaria que les dio sentido en el pasado.

La imposición de una religión extraña motivó cuestionamientos de pertenencia e identidad que envolvió a los conversos en una dinámica de ocultamiento en la que se disolvían los límites entre el ser y el deber ser: ¿cómo reafirmar lo prohibido?, ¿cómo permanecer fiel ante la fe con el riesgo de perder la vida? La falta de libertad los obligó a la clandestinidad, cuyas consecuencias fueron la distinción entre lo legal y lo ilegal, las diferencias entre los jueces y quienes eran juzgados, las concepciones entre lo verdadero y lo falso. De acuerdo con las circunstancias dadas, los criptojudíos trataban de mantener el arraigo a su fe, adecuando ciertas prácticas rituales aprendidas de sus ancestros, defendiendo el monoteísmo y manteniendo rasgos del sentido de identidad, tanto en grupo como individualmente. El resultado fue el empobrecimiento de su judaísmo y la asimilación mal entendida del cristianismo.

Este trabajo tiene como finalidad exponer la problemática con la que se enfrentaron los criptojudíos al interpretar la "Ley de Moisés". Ante el miedo que provocaba la censura inquisitorial, se observa el desgaste y la transformación de la religión oficial judía, de la cual quedaron sólo símbolos mutilados, pero resignificados para los conversos de la Nueva España.

Es sabido que los judíos, como cualquier grupo reconocido, construyen su identidad mediante la distinción de creencias y prácticas que los diferencian de otros grupos, en un marco social de aceptación. Así, se perciben distintas formas de entender la realidad: hacia el interior del grupo hacia el exterior, es decir, confrontando lo propio con lo ajeno.

A lo largo de la historia, los judíos reprodujeron su cosmovisión, fundamentada en los libros sagrados. Como parte de la ideología creada y sustentada por el grupo, la concepción religiosa planteaba un determinado orden de la realidad en cuanto a los elementos simbólicos del mundo, que permitía la sociabilidad humana. Proponía, así mismo, un orden ideal donde se percibían varias dimensiones, una de ellas era la propuesta espiritual, y otra, la moral y social, las cuales, al asumirlas, establecían una forma de vida reafirmando su propia verdad. Desde la perspectiva intrínseca, la estructura estaba supeditada a prácticas y creencias basadas en la dimensión divina. 
Tanto los roles sociales, como las dinámicas del comportamiento cotidiano y ritual tenían su referente en los libros sagrados oficiales. En este sentido, el predominio patriarcal era el que se transmitía de una generación a otra. La pirámide estructural posicionaba, por tanto, a los rabinos como la máxima autoridad, pues estaban encargados de resolver conflictos, tanto mundanos como espirituales. Eran ellos, junto con los demás varones, quienes transmitían el legado normativo basándose en las leyes santas, pues tenían acceso al conocimiento litúrgico que determinaba al resto de la sociedad. Las mujeres, por su parte, situadas en un nivel inferior, tenían la misión de educar a los hijos (hasta los trece años) y cuidar de las leyes mosáicas — que adquirían de manera diferida - dentro de la casa.

Desde esta perspectiva, se perfilaban, a grandes rasgos, la religión oficial del deber ser, y la visión doméstica, a cargo de las mujeres, que interpretaban a su modo el legado bíblico ${ }^{4}$. Así se afianzaron rasgos identitarios que envolvían redes de parentesco, roles sociales, diferencias de clases, comportamientos y creencias que cada individuo reproducía en el ámbito comunitario. Al adecuar los paradigmas heredados del judaísmo a las circunstancias existenciales de las distintas diásporas, surgieron diferencias en torno a la interpretación de los textos bíblicos; estas diferencias le brindaban ciertas particularidades a cada comunidad judía establecida en los diversos territorios.

Sin embargo, las normas que regían las dinámicas sociales dentro del grupo tenían que ver con las que se delimitaban fuera de él; por lo tanto, tendían a presentarse dualidades conceptuales: el bien y el mal, lo sagrado y lo profano, lo aceptado y lo rechazado, la autoridad del rabino ante los estatutos prevalecientes en el contexto, etc.; todo ello conformado en un universo que trataba de mantener el equilibrio mediante el entendimiento entre el legado cultural milenario y el mundo en el que estaban insertos.

La mayoría de los conversos que llegaron a la Nueva España fueron de origen portugués, pues al unirse los territorios de Portugal y España se impusieron las mismas leyes de rechazo que ejecutaron los Reyes Católicos. A su llegada al nuevo continente, ya cargaban con la consigna de exclusión social que los posicionaba en un nivel marginal autorizado. Los conversos vivían en los

\footnotetext{
${ }^{4}$ Es de hacer notar que el equilibrio no siempre tiene que ver con la equidad, es decir, si es una sociedad patriarcal, por ejemplo, el ideal social implica la predominancia de los hombres sobre las mujeres.
} 


\section{FRONTERAS}

de la historia

límites de una estructura jerarquizada que los denigraba, pero, al mismo tiempo, reforzaba los andamios que sustentaba el poder.

De esta manera, la cohesión social diferenciada de los judaizantes se vio despojada de sus parámetros regidores que definían al grupo en sus dinámicas sociales. Los criptojudíos novohispanos estaban envueltos en una confusión de ideas y acciones que los forzaban a contradicciones y malos entendidos en torno a la práctica religiosa, característica primordial para reforzar su identidad. Al establecerse, principalmente en las ciudades, trataron de reproducir las prácticas y creencias conocidas, aunque veladas a los ojos de la mayoría de la población. Durante los primeros años la censura representó una amenaza controlada, pues aunque debían ser discretos en las prácticas rituales propias del judaísmo, se logró conformar un grupo criptojudío en el que se reconocían unos a otros. Las reuniones religiosas se efectuaban en la clandestinidad, generalmente en casas particulares, con personas cercanas y con el cuidado necesario para no ser descubiertos. Durante este lapso, en los años previos a 1642 (cuando se intensificaron las persecuciones inquisitoriales a los judaizantes), también se fomentaban los matrimonios endogámicos, haciendo funcionar la maquinaria de relaciones y redes de parentesco que los identificaba. Los criptojudíos trataban de mantener líneas de reconocimiento mutuo. En este sentido, cuando el peligro de persecución disminuía, la solidaridad grupal se intensificaba:

[...] los recién llegados de Europa, que no dejaban de encontrar en Nueva España a algún pariente cercano o alejado, o un conocido de su ciudad o aldea, tenían asegurada la casa, la comida, la introducción en las familias amigas y la colocación en un primer empleo; la comunidad movilizaba las influencias cuando algún miembro del grupo tenía que vérselas con la justicia, premiaba con regalos diversos a los judaizantes que [...] habían callado lo que sabían acerca de sus correligionarios, o también ayudaba con limosnas de toda clase a los más desvalidos, los enfermos, las viudas, pobres, etcétera. (Alberro 442)

Sin embargo, debido a la carencia de libertad, los criptojudíos no lograron institucionalizarse como comunidad, más bien, se comportaban de manera fragmentaria y dispersa, sin un centro regidor que los convocara y estructurara. En primer lugar, estaban desprovistos de autoridades religiosas que los guiaran en torno a los rituales. El rechazo social generalizado en el entorno y el miedo a los juicios inquisitoriales provocó la desaparición de rabinos y estudiosos de la Ley de Moisés, por lo que sólo se recurría a la memoria trasfigurada para cumplir con los preceptos. En segundo lugar, el concepto de comunidad se vio mermado bajo la mirada de la sociedad mayoritaria cristiana, por lo cual, 
aunque se reconocían unos a otros en ámbitos clandestinos, evitaban ser vistos a la luz pública.

Era sabido que para la celebración de los rituales de paso en el proceso de vida, según los lineamientos bíblicos, se requería la presencia de correligionarios que avalaran la integración de nuevos miembros a la comunidad, para promover la reproducción y trascendencia ideológica; este aspecto se demeritó en el contexto colonial. En el ambiente de censura en el que vivían los judaizantes, se vieron amenazadas las esperanzas de proyectar hacia el futuro su cosmovisión. El resultado consecuente fue la alteración de la ortodoxia. La falta de conocimiento en el desempeño de los rituales y la carencia de objetos sagrados limitaron las prácticas religiosas y, en consecuencia, también la perspectiva simbólica de la religión concebida según la perspectiva práctico-espiritual de una colectividad. Así, el legado cultural, entendido como un sistema de concepciones y símbolos que los individuos reproducen para perpetuar su conocimiento y sus actitudes a través del tiempo, se distorsiona en fragmentos y pierde la visión del conjunto.

La ausencia de sinagogas, del aprendizaje de la lengua hebrea como símbolo identitario, del estudio de los textos sagrados y de las prácticas rituales celebradas para el ciclo de vida y el ciclo anual modificaron el entendimiento de su fe mosaica. El ambiente de rechazo en que se vieron sometidos distorsionó el sentido de la diferencia como grupo organizado e institucionalizado. Si la identidad se relaciona con el significado de singularizar, de distinguirse como unidad en el tiempo y en el espacio para proveer un consenso cultural en el que se reconozcan unos a otros en un marco de alteridad, en la Nueva España sólo quedaron reminiscencias de ese reconocimiento mutuo, rasgos esporádicos de un arraigo al culto, identificadores cojos que representaban la esperanza mesiánica de la redención. Los criptojudíos pisaban un punto limítrofe entre el desarraigo y el sentido de pertenencia, ambigüedad que extirpaba la posibilidad de identidad, pues se anulaba su diferencia ontológica.

Adentrándonos detenidamente en ciertos aspectos de las transformaciones que constituyeron la cosmovisión de los cristianos nuevos, se percibe una inversión de géneros en los comportamientos relacionados con la transmisión de la religión, ya que en este contexto eran las mujeres las que promovían a su entender la reproducción de valores y prácticas religiosas que en circunstancias de libertad estaban a cargo de los hombres ${ }^{5}$. La estructura social en la que se

\footnotetext{
${ }^{5}$ Es propio de los hombres transmitir el legado del judaísmo oficial, pues son los encargados de dirigir las ceremonias religiosas, así como de estudiar las interpretaciones de los textos sagrados.
} 


\section{FRONTERAS}

de la historia

posicionaban las jerarquías y se definían los roles sociales sufrió un desfase, ya que el secreto y la desconfianza de observadores cristianos impedían a los conversos reconocer autoridades o representantes comunitarios de acuerdo con las usanzas del pasado, por lo que las mujeres adquirieron el papel de promotoras espirituales. En ellas se depositaba la esperanza de salvación. Las motivaba la idea mesiánica de redención, pues el arraigo a su fe prometía la llegada de un mundo ideal, por lo que el sacrificio era parte fundamental para hacerlo realidad. En cierta medida, era lógico el afianzamiento a lo conocido y la necesidad de reproducirlo, pues daba sentido a las incongruencias de su presente. Trataban de reconfigurar y reafianzar el reconocimiento que les permitiera delimitar las fronteras para lograr cierta homogeneidad y pertenencia y, así, proyectar su continuidad ideológica e histórica. Hay testimonios archivados de judaizantes que reflejan la necesidad de transmitir su legado cultural ancestral:

[...] cuando la dicha Justa Mendes le trató de [la dicha Ley] de Moisés y le dijo que era la mejor para salvarse, se acuerda y así mismo [que] le dijo y enseñó los ritos y ceremonias que $\mathrm{d}[\mathrm{ebe}]$ guardar en su guarda y observancia [...] (AGNM, I 403, exp. 3a, f. 323v.).

La devoción que las mujeres manifestaban en su fe las convertía en medios por los cuales sus correligionarios más ricos expiaban sus culpas, haciéndolas responsables de sus ayunos u oraciones requeridas en los rituales. Por lo tanto, ellas sustentaban la religión interpretándola a su entender, dando consejos a quien acudía a pedirlos o haciéndose cómplices de confesiones afectivas. A cambio, estas mujeres recibían limosnas, regalos y reconocimiento entre el grupo marginal. Un ejemplo claro es el testimonio de María de Rivera:

Y que así mismo, ha hecho como veinte ayunos de los ordinarios de la dicha ley, en tiempo de seis años, poco más o menos, por vivos y difuntos; y en especial por una doña Clara de Silba, mujer de Diego Juarez, que no sabe dónde está y que hizo por ella un ayuno, y le dio de limosna porque lo hiciese un peso, su hermana doña Blanca Enrriquez, difunta, suegra de Simón Vaez Sevilla. Y que por la dicha doña Blanca Enrriquez, después que murió, hizo esta confesante tres de los dichos ayunos, sin que por ellos recibiese limosna alguna, sino por el amistad [sic] y amor que le tenía y esta confesante [...]. (AGNM, I 403, exp. 3a, f. 324v.)

El conocimiento de la lengua hebrea sólo era accesible para ellos, en tanto que las mujeres desempeñaban roles de la maternidad y el buen funcionamiento de las reglas del hogar. 
Ante la tajante prohibición de practicar el judaísmo, se dispararon numerosas actitudes. En la mayoría de los casos era en el hogar, en el seno familiar e íntimo, donde se descubrían los secretos, se desprendían de las máscaras aparentes $^{6}$. Así, las mujeres eran las que fomentaban las redes de parentesco entre primas, hermanas, hijas, tías y abuelas para delimitar las formas rituales lejanas y semiolvidadas que querían reproducir:

Y desde el dicho tiempo tiene por cie[rto] que la dicha doña Juana de Silba y sus hermanas, que ha referido, y su madre doña Blanca, difunta, tuvieron a esta confesante y a la dicha su madre y hermanas, así mismo por observantes de la dicha Ley, porque se lo debió de decir la dicha Justa Méndez y desde entonces no se recataren una de otras, teniéndose todas por unas y de una creencia y profesión de la dicha Ley de Moisés [...]. (AGNM, I 403, exp. 3a, f. 325v.)

Los edictos de fe, dictados por los inquisidores, que periódicamente se leían en público, daban cuenta de cómo se podía identificar a un judaizante a partir de sus usos y costumbres, y amenazaba con excomunión a los quienes no los denunciaran. Por ello, las prácticas de los judíos se disimulaban de tal forma que no se le confesaba al hijo su religión hasta que éste cumplía los trece años (para celebrar su bar mitzvá). El peligro que representaba la celebración amenazaba tanto al muchacho como a la familia entera. Si no estaba circuncidado bajo el ritual correspondiente (brith milá), se procuraba hacerlo en esa época. Igualmente, los demás rituales del ciclo de vida y del ciclo anual o el desempeño de los rezos para el shabat se fueron adecuando al encubrimiento, al carácter dual y ambiguo que se reflejó a lo largo de los años en la mezcla de identidad, pues no practicaban su judaísmo pleno ni el catolicismo impuesto. Aun así, los lazos de parentesco y la identificación entre los correligionarios era común: un converso sabía siempre de otro, y la ayuda mutua se manifestaba la mayoría de las veces.

[...] en el transcurso de las migraciones, fallecimientos, casamientos, nacimientos, prisiones y hogueras, se trata, en definitiva, de una misma red familiar, religiosa, comercial, afectiva, que se reconstituye incansablemente [...]. No son siempre las mismas personas: es evidente que éstas cambian, viajan, envejecen, desaparecen: aparecen nuevas generaciones y las configuraciones de grupo se modifican, se recomponen, se reestructuran; pero lo que parece reproducirse son los lazos de solidaridad que los unen entre sí, y que permiten siempre el recibimiento de nuevos migrantes. (Wachtel 103).

\footnotetext{
${ }^{6}$ Sin embargo, en ocasiones, algún miembro de la familia pertenecía a una orden religiosa cristiana como recurso para aparentar su verdadera creencia. Esto provocaba conflictos en el mismo seno familiar, pues la contradicción dominaba sobre la intención.
} 


\section{FRONTERAS}

de la historia

Vol.12 / 2007

De esta manera vivieron por siglos ${ }^{7}$. Es paradójico cómo, en ocasiones, las mujeres recurrían a los mismos edictos públicos del Santo Oficio para conocer las prácticas que debían ejecutar:

[...] a falta de una verdadera enseñanza religiosa, la lectura de los edictos de fe promulgados por el Santo Oficio, en los que se describen las principales prácticas mosaicas, constituye el medio más importante para los judaizantes mexicanos de conocer su religión, en un extraño ejemplo de situación en que la herramienta represiva se transforma en agente difusor de los comportamientos que pretende reprimir, al convertirse la institución inquisitorial en auxiliar involuntario de la disidencia [...]. (Alberro 419).

Muchas veces el desconocimiento de cómo realizar un ritual determinado, forzaba a las mujeres a recurrir a elementos culturales ajenos que provocaban sincretismos difíciles de distinguir. La degeneración de la religión derivaba en interpretaciones parciales que se manifestaron en rasgos identitarios carentes de fundamentos autorizados y reforzados por la cohesión de una estructura sociorreligiosa afianzada. La religión, más que fomentar alianzas y reconocimientos públicos, se entendía interpersonalmente, es decir, la necesidad comunitaria de la ortodoxia pasaba a segundo término, optando como única alternativa por la complicidad entre un sujeto y otro para afirmar su pertenencia.

Es lógico pensar que mientras hubiera mayor consenso entre el grupo de judaizantes, mayor era su capital humano, es decir, más confianza se tenían unos a los otros y más fuerza tenía la práctica. Sin embargo, entre mayo y julio de 1642 se rompió la estabilidad condicionada y precaria, al recrudecerse la persecución masiva de judaizantes por el aparato inquisitorial. Las cárceles secretas se atiborraron de herejes que, ante el peligro, tenían que reformular sus esquemas valorativos para agradar a las autoridades en los juicios y esperar su misericordia. Cuando cundió el terror entre el grupo converso, se desbarataron los lazos de solidaridad. Esta dinámica de incertidumbre provocó en los criptojudíos, desconfianzas y ambivalencias, conflictos internos y externos, primero ante los cristianos, y luego también entre ellos mismos, pues nunca se sabía quién iba a delatar al otro.

Ante el Tribunal, el miedo, que inhibía a la razón, hacía que los confesantes actuaran sin saber realmente lo que les convenía. El decir o no decir provocaba

\footnotetext{
${ }^{7}$ Sólo después del siglo XIX se abrió el panorama para la libre aceptación religiosa en México. En pleno siglo XIX todavía se "ordenaba que no se permitiera salir en tierra a los judíos, ni internarse en ninguno de los dominios de España". Gojman 68.
} 
enredos que ni ellos mismos sabían resolver. Las comunicaciones que se realizaban en las cárceles manifestaban esta incertidumbre, pues las alianzas o traiciones se hacían entre los muros de las celdas, a veces agujereados y carcomidos de tanta humedad, a través de los cuales se pasaban información del destino de sus conocidos. Además, comentaban la dinámica que se llevaba en los juicios, la postura de los inquisidores, el sistema que utilizaban para extraer nombres de culpables y los métodos de tortura. La palabra diferida entre un mensaje y otro podía magnificar los hechos o transformarlos, pero era el único acceso que tenían los presos para conocer la lógica y las reglas con las que funcionaba el engranaje del poder. En las comunicaciones de las cárceles, los cautivos también se daban cuenta de quiénes eran los que, dentro de sus conocidos, habían cedido a la traición y quiénes permanecían fieles a sus semejantes mediante el silencio. Un ejemplo claro de la postura de solidaridad se percibe en el diálogo que entablan Leonor Vaez y su hermano Gonzalo, en el que se dan ánimos para permanecer firmes en sus convicciones, en no ceder ante las autoridades y mantenerse en silencio:

Y la dicha Leonor Vaez le volvió a decir: "Pues no decirlo y pasar como pudieres, hasta salir, que importa; yo tampoco no sé nada". Y Gonzalo le dijo que cuando le suben arriba, dice que esta de ido, que quiere decir loco; y luego lo bajan otra vez y no tiene remedio, que no medran con él nada, que dice: "que no sé", y cuando visitan también. Y Leonor Vaez le dijo: "Bueno es eso para negociar, sufre y los vencerás y te librarás que es lo que te importa a ti y a mí; y a todos muélelos y dales a merecer". Y Gonzalo le respondió: "Así lo hago y lo haré hasta el fin, se canta la gloria y no han podido que diga [...] como ellos quieren, ni el sí, señor" (AGNM, I 403, exp.3, f. 115v.).

Es pertinente detenernos en la disyuntiva que implicaba esta decisión, ya que por un lado englobaba la perspectiva ética y moral de la acción ante el otro, en cuanto fidelidad y apoyo, pero con el peligro de ser sentenciado a muerte. Por otro lado, también se manifestaban actitudes más débiles en las que el miedo rompía con la firmeza de permanecer en silencio, lo que terminaba con toda expectativa de alianza que se tenía del compañero. Ante ello, nos preguntamos, ¿se puede juzgar al delator?, ¿qué tan efectivo era mantener los lazos afectivos o identitarios?, ¿la solidaridad brindaba más certidumbre que la infidelidad? Nos damos cuenta de que las decisiones se tomaban individualmente, sin un patrón de comportamiento unificador: cada quien decidía sus posiciones de acuerdo con sus convicciones, que nunca eran definitivas, pero que brindaban, en la medida en que las circunstancias inciertas lo permitieran, cierta estabilidad y congruencia entre sus creencias y sus actos. 


\section{FRONTERAS}

de la historia

De esta manera, la postura de dar prioridad a la supervivencia individual a costa de la denuncia, o resisitir a la presión de las autoridades dando crédito a la solidaridad y confianza en el otro semejante, creaba cuestionamientos existenciales extremos en los que era necesario decidir la aceptación de las autoridades y el rechazo del grupo judaizante o la solidaridad con dicho grupo, pero asumiendo la amenaza de tortura y muerte.

El ejemplo que enseña la postura de la delación para procurar la liberación se registra en un fragmento de María de Rivera, en el que iba revelando nombres de culpables conforme realizaba su confesión:

[...] que, efectivamente, hizo [...] ella de la dicha Ley de Moisés, y con el dicho su hijo, si bien hab[ía] más de once años, poco más o menos, que sabía esta confesante que la dicha doña Juana de Silba y su madre, doña Blanca Enrriquez, difunta, y sus hermanas: doña Catalina Enrriquez, mujer de Diego Tinoco; doña Raphaela Enrriquez mujer de Gaspar Juarez; doña Michaela Enrriquez, mujer de Sebastían Cardoso; doña Beatriz Enrriquez, mujer de Thomas Nuñez de Peralta, eran observantes de la dicha Ley de Moisés [...]. (AGNM, I 403, exp. 3a. f. $325)^{8}$.

La reacción de los presos ante la traición implicaba el lógico rechazo hacia el delator. En la misma cárcel se sabía quién había cedido a las presiones de los inquisidores y quiénes no. Un caso específico es el de la misma Leonor Vaez cuando conversa con su hermano Gonzalo y se refiere a las mujeres de la familia Rivera de manera peyorativa con el apelativo de "las blancas" (la madre se llamaba Blanca de Rivera), pues gracias a ellas, se dieron a conocer varios nombres de judaizantes que también fueron encarcelados y juzgados:

Dijo Leonor Vaez: "Y aquí donde estoy, tengo mucho cuidado en hacer [a]quello (que es el ayuno) con mucho asco y limpieza para que nos ayude y seamos libres y lo haré esta semana por [ti], porque negocies y salgas y desmientas a las blancas". (AGNM, I 423, exp. 3, f. 115v.)

Es aquí cuando salen a relucir, según los testimonios de la gente que declara en contra de los sospechosos, ciertos identificadores que los condenan o los exculpan. Uno de ellos era el ayuno del Día Grande, es decir, del Yom Kipur, la celebración más importante en la religión oficial judía. Este ritual tiene como finalidad la expiación de los pecados, reflexionar sobre los actos indebidos y la reconciliación con el prójimo. Para los criptojudíos era necesario cumplir los

\footnotetext{
${ }^{8}$ Subrayada en el original.
} 
requerimientos de esta festividad, pues la imposición de prácticas contrarias a sus creencias (como adorar ídolos y transgredir la concepción de Dios omnipotente y omnipresente) les hacía sentirse culpables y pecadores. El ayuno tranquilizaba su conciencia, pues en cierto sentido los redimía y reafirmaba su esperanza de salvación. Respetar el día sagrado los mantenía conectados con sus ancestros, con su libertad, con el legado milenario de su judaísmo; por ello las trasgresiones que se veían obligados a realizar, como negar su religión ante el público, ir a misa y pronunciar oraciones cristianas o venerar a la Virgen, pasaban a ser secundarias en su conciencia si cumplían con el ayuno.

Es interesante resaltar cómo el rito pretendía bastarse a sí mismo, aislarse parcialmente de los contenidos oficiales del judaísmo para producir resultados en los que no mediase una experiencia de fuerte convicción interior de lo sagrado, ya que los principios espirituales se tambaleaban cada vez más. "Toda interpretación que considere los 'No harás' tal o cual cosa del Antiguo Testamento por separado, sin visión del conjunto, está condenada al fracaso" (Douglas, Pureza 72).

De esta manera, cuando se incrementaron las acusaciones que distinguían a los judaizantes de los cristianos viejos, los delatores enfatizaban la práctica de no comer ni beber durante un día. Se trataba de descubrir los detalles en sus acciones cotidianas para fundamentar la acusación, pues en ellos residía el pecado. A partir de este momento, los criptojudíos se vieron en la necesidad de defenderse, lo que motivó contradicciones, negaciones, encubrimientos y mentiras que los culpables utilizaban para minimizar sus actos.

En los testimonios es posible distinguir dos momentos en la valoración de principios religiosos de los judaizantes: por un lado, la actitud de una temporalidad anterior a la década de $1630^{9}$ en la que había mayor tolerancia de los inquisidores y en la que se fomentaron parcialmente las prácticas rituales, y por otro, el momento de ser aprehendidos al presentarse ante los jueces para declarar su inocencia. La perspectiva cambia, ya que desaparece la confianza que se tenían entre ellos en el pasado, y en algunos casos se utiliza en sentido

\footnotetext{
${ }^{9}$ Según Wachtel, "la ola de represión comienza el 22 de marzo de 1634, con el arresto de Isabel Lopez Cardado; el 24 de marzo, es detenido su marido, Baltasar del Valle. Algunos meses más tarde, el 23 de agosto, un personaje central, Antonio Fernández Cardado, también es encarcelado en las celdas inquisitoriales" (108). Alberro afirma, por su parte, que "a fines del siglo XVI y en el decenio 1640-1650 -excluyendo los años 1630-1635, en los que la persecución no fue sistemática-, sufrieron fuertes persecuciones, al término de las cuales sus comunidades quedaron destruidas sin remedio" (172).
} 


\section{FRONTERAS}

de la historia

contrario, es decir, para culpar al "otro" y salvarse "ellos". Los hechos se tergiversan en otro sentido, utilizando toda evidencia, que en otro tiempo fue de identificación, para desligarse de ellos. De esta manera, unos hacían ver que fueron otros los que los embaucaron para no comer ni beber un día entero. Es el caso de María de Rivera, quien acusa a Ana Enríquez de inculcarle las prácticas del judaísmo:

[...] doña Blanca de Rivera enviaba a esta confesante algunas veces a casa de la dicha doña Ana Enrriquez su tía, que estaba con su hija doña Isabel Duarte, que sería entonces de catorce a quince años de edad, poco más o menos, le dijo a esta confesante que si se atrevía aquel día a estar en ayunar sin comer hasta la noche y esta confesante, como era niña le respondió, que sí haría; y en Dios y en su conciencia no se acuerda si le dijo la dicha doña Ana Enrriquez otras palabra[s] y circunstancias [y] la dicha su hija doña Isabel Duarte, la que sí se acordará las dijera llanamente. Y que las dichas dos, madre e hija, estuvieron en ayunas todo aquel dicho día sin comer, hasta la noche y no se acuerda, como ha tanto tiempo, lo que cenaro[n] o pasó el dicho día. Y que como esta confesante era muchacha y tenía hambre, comió a escondidas unos higos y bebió agua sin saber por entonces qué era aquello que las dichas mujeres ha[...] hacían y le mandaron hacer estar en ayunas todo el día y nunca más en España hablaron las dichas doña Ana Enrriq[uez] y doña Isabel Duarte, en razón de que ayunase otro día, ni esta confesante por ser tan niña reparó en ello, ni le dio cuidado. (AGNM, I 403, exp. 3a, ff. 322r.- 322v.)

Como se observa, la confesante María de Rivera acusa a Ana Enríquez de embaucarla en la práctica del ayuno, hecho que no respetó porque "era muchacha" y "tenía hambre". Pero más que el pretexto, se lee entre líneas el propósito de decir lo que los inquisidores quieren escuchar para que tomen una actitud benevolente con ella. En la palabra se inserta la sospecha, pues encubre otra verdad: el discurso se torna ambiguo al estar cargado de una intencionalidad orientada a la aceptación, recurriendo a la estrategia de la apariencia.

La necesidad de hacer creer que los culpables son los "otros" es un subterfugio en la que ella se posiciona como víctima de la influencia indebida. La estrategia consiste en remarcar dualidades: el bien y el mal, lo sagrado y lo profano, etc. Si ella es "buena" como sus jueces, los otros son "malos", aunque tenga que traicionar a su misma gente. Otro testimonio de María de Rivera, en su confesión del 20 de mayo de 1642, vuelve a relucir cómo fue manipulada, ahora por Justa Méndez, para que practicara el ayuno: 
[...] la dicha Justa Mendez le dijo un día a solas a esta declarante tratando de sus sucesos que había tenido en este Santo Oficio: ven acá María, ¿no eres tú de los nuestros?, y esta confesante le respondió que, ¿qué quería decir en aquello?, y la dicha Justa Mendez le respondió que lo que quería decir era: que había de ayunar en un día entero; y esta le respondió que: ¿para qué? Y entonces la dicha Justa Mendes, le dijo que para salvarse guardando la Ley de Moisés en que se hacían algunos ayunos y especialmente el día grande y que la dicha Ley de Moisés era la buena, verdadera y necesaria para la salvación y no la de Jesucristo, nuestro Señor, que esta confesante profesaba, que era falsa e iba errada en seguirla; persuadiéndola en esta ocasión a que se pasase a la fe y creencia de dicha Ley de Moisés [...]. (AGNM, I 403, exp. 3a, ff. 304r.-304v.)

El proselitismo que se percibe en la cita anterior era una de las características del comportamiento de las mujeres antes de 1642, pues, como se dijo, eran ellas las encargadas de fomentar y proyectar la religión en las siguientes generaciones. El hecho de que unos traten de influenciar el comportamiento de otros refuerza las presiones sociales, ya que se comparte la inconformidad o el miedo. Además, se manifiesta la necesidad de identificación: “¿no eres tú de los nuestros?", lo que implica la diferenciación respecto a "los otros".

Es sabido que hablar de judaísmo es remitirse a la dimensión colectiva y comunitaria, religiosa y social, a la concepción de pertenencia histórica, elementos que confieren un distintivo, que al trasladarlo al contexto novohispano se coartan ante el antagonismo que prevalece en el ambiente. La necesidad de mostrar el lado opuesto a lo que se es, genera un doble discurso: "La dicha Ley de Moisés era la buena, verdadera y necesaria para la salvación y no la de Jesucristo, nuestro señor, que esta confesante profesaba, que era falsa e iba errada en seguirla".

Al mencionar lo contrario, se enfatiza la verdad oculta. La necesidad de crear un orden que provea una estructura donde asentarse, era lo que motivaba a categorizar dualidades entre el adentro y el afuera, entre estar a favor o en contra.

Por otro lado, la temática de la cita se detiene en el ayuno, como pauta que delimita la sentencia. Así, el ayuno, por un lado, funcionaba (antes de 1642) como rasgo identitario que cohesionaba al grupo disperso y confundido ideológicamente, pero, por el otro, era el referente que llevaba a la condena cuando estaban ante los inquisidores. Así, la distancia temporal mediaba entre una actitud y otra, ya que las circunstancias cambiantes entre la tolerancia y la rigidez de los parámetros regidores les transforma su posición ante el mundo. 


\section{FRONTERAS}

de la historia

Vol.12 / 2007

En el testimonio que pronuncia Isabel Tinoco contra María de Rivera constatamos de nuevo cómo el ayuno servía como identificador de la Ley de Moisés:

[...] fue en ayunas a casa de las dichas doña Blanca de Rivera y su hija doña Ysavel de Rivera, la quizo dar chocolate y esta confesante no lo quiso beber; y como también le había dicho la dicha su abuela que la dicha doña Ysavel y su hermana doña Clara así mismo eran observantes de la Ley de Moisés, fácilmente le dijo esta confesante a la dicha Ysavel que no quería beber [...] chocolate porque ayunaba aquel día [en] guarda y observancia de la dicha ley, como con efecto le ayunó, estándose sin comer hasta la noche, en compañía de la dicha doña Ysavel y de doña Margarita, su hermana, que también ayunaban, declarándose todas tres, las unas con las otras por observantes de la dicha ley [...]. (AGNM, I 406, exp. 1, ff. 8r.-8v.)

Como se observa, el ayuno practicado en un pasado inmediato era un marco de referencia para la identificación de un individuo y otro. En el momento en que se reconocían, formaban una complicidad que no sólo implicaba la ausencia de alimento, sino la clandestinidad. El hecho formaba lazos solidarios que implicaba la diferenciación, aunque sea velada, respecto a la mayoría cristiana. Pero para mostrar la confianza, para hacer saber al otro sobre sus prácticas prohibidas, tenían que actuar con cautela ("la quizo dar chocolate y esta confesante no lo quiso beber") provocando trampas, poniéndose a prueba, captando rasgos y actitudes en común hasta que se revelara lo oculto.

[...] preguntó esta confesante a la dicha su abuela si las dichas doña Blanca y sus tres hijas María, Margarita y Catalina, guardaban la Ley de Moisés, a lo cual la dicha doña Blanca respondió que eran buenas cristinas y guardaban la ley que ella seguía y había enseñado a esta confesante. Y le preguntó la dicha su abuela si se podía fiar de ellas, a que le respondió que sí, pero que no tuviese muchas pláticas. (AGNM, I 406, exp. 1, f. 8r.).

Es cierto que, desde la forma, abstenerse de la comida y la bebida durante un día específico es un rasgo del ritual judío que sustenta lo espiritual. En los parámetros bíblicos se lee cómo hay que actuar en la celebración, conectando la experiencia corporal con el ámbito sobrenatural. En el Yom Kipur culminan los días del arrepentimiento (que inician en el Rosh Hashaná o año nuevo judío) y se juzga al individuo para que Dios lo inscriba en el "Libro de la vida":

[...] ningún trabajo haréis; tanto el nativo como el peregrino que mora en medio de vosotros; porque en ese día se hará expiación por vosotros para purificaros; de todos vuestros pecados quedaréis puros ante el Eterno. [Como] sábado solemne 
será para vosotros, en el cual habéis de afligir vuestras almas; estatuto perpetuo es. (Lev. 16: 30-31).

Los textos considerados sagrados estipulan que hay que comer una cena liviana, luego de la cual se inicia el ayuno. El servicio religioso en la sinagoga comienza siendo aún de día. Generalmente los asistentes se visten de blanco, además los hombres se cubren con el talit (manto ritual). Se dice la kal nidre (oración que revoca los votos, contra Dios o contra su prójimo, que asumió una persona de manera involuntaria durante el año transcurrido), que da inicio al día más sagrado del año, por lo que se pronuncia con profunda emotividad frente a la Torá (rollos del Pentateuco). Después de la oración referida, se procede al servicio de arvit (oración vespertina cotidiana). Acto seguido, se agrega la oración de minjá (servicio vespertino) y, finalmente, se expresa un servicio más: ne'ilá (oración que cierra las plegarias del Yom Kipur). Inmediatamente después de la secuencia estipulada se hace sonar el shofar (cuerno de carnero) que señala la terminación del ayuno. Entonces los feligreses se desean felicidades diciendo: "El año que viene en Jerusalén". En todos los oficios se agregan poemas litúrgicos y plegarias (slijot), cuya temática es el perdón por las trasgresiones cometidas y la petición de redención. Además, durante el transcurso del día de ayuno se leen pasajes del libro de Ieshaiáhu (Is. 57, 58) y por la tarde, un texto del libro de Ioná (Jonás) que reafirma el arrepentimiento.

Según la tradición, este es el día en que Dios dicta sentencia sobre todo ser humano para el año entrante. Por ello, la promesa que fomenta el ritual trascendió entre los criptojudíos, pero de manera trunca, pues ni la presencia comunitaria, ni los rezos, ni los cantos litúrgicos se conocían "[...] y que no le enseñó la dicha Juzta Mendez [sic] oración alguna de la dicha Ley [...]" (AGNM, I 403, exp. 3a, f. 324r.).

Así, cada quien recurría a lo que sabía para construir un relato espiritual que les diera sentido. Había mujeres que sabían más que otras en materia religiosa, por lo que fungían como autoridad. Blanca Enríquez, por ejemplo, creía fervientemente en la llegada del Mesías, y defendía a toda costa las prácticas rituales que, no obstante, distaban de tener sustento ortodoxo. En este sentido, sus interpretaciones adquirieron verosimilitud y, por lo tanto, autoridad.

De acuerdo a las enseñanzas religiosas que transmite Justa Méndez, que también trata de legitimar las leyes mosaicas, observamos que hay ciertos elementos que corresponden a los lineamientos bíblicos ortodoxos: 


\section{FRONTERAS}

de la fistoria

[...] y vestirse ropa limpia [los] viernes en la tarde o los dichos sábados, y que se habían de [ilegible] por el mes de septiembre a los diez días de la luna del $\mathrm{Lu}[\mathrm{nes}]$ del día grande, bañándose la vísper[a] dellos, y vistiendo [...] ropa limpia, y cenando aquella noche pescado, y leg[umbres] y no carne, y encendiendo después una vela de cera y [...] poniéndolas sobre un lienzo limpio, y que se habían de pedir unos a otros, y reconciliarse los que estuviesen enemistados y echar la bendición los padres a los hijos, poniéndoles la mano en la cabeza y diciéndoles de Dios, seáis benditos; y que mientras ardían las candelas sin apagarse, se habían de encomendar a Dios, rezando las oraciones que supiesen de la dicha Ley, o lo que cada persona supiese hasta que se cansasen, y se acostasen a dormir. (AGNM, I 403, exp. 3a, f. 324r.).

Es importante resaltar que este testimonio recuerda la época de mayor tolerancia ante los conversos, en un tiempo distante al momento de la declaración expresada en 1642, por lo que se observa más estructuración y claridad en la manera de concebir los rituales. Las prácticas se apegan en cierta medida a los dictados bíblicos, pero en su interpretación ya está implícita la violación de algunos elementos. Más que nada, se tratan de respetar las formas, en este sentido, bañarse y vestir ropa limpia, que recuerdan, en la tradición religiosa, la purificación simbólica, pero que en el contexto novohispano representan actos sin sustento conceptual, sólo son referentes del deber ser sin contenido espiritual. El "lienzo limpio" era la simulación del talit o manto ritual que implica un precepto permanente en el ámbito ortodoxo. Tradicionalmente posee flecos en sus cuatro vértices y está hecho de lana blanca, seda o algodón. Lo utilizan los varones, desde que son iniciados en el ritual de bar mitzvá, en todas las oraciones matutinas y en las festividades mayores (como el Yom Kipur), así como en las bodas, con el que se cubre a los novios o, por otro lado, a los muertos cuando son conducidos a su sepultura. Desde el nombre, ya se nota una desviación de la percepción del objeto sagrado, pues el término en hebreo talit, ya está cargado con un significado consagrado, no así, "lienzo limpio", que puede se cualquier tela.

Por otro lado, también se menciona, como en el texto bíblico, la restauración de alianzas con el prójimo ("se habían de pedir unos a otros, y reconciliarse los que estuviesen enemistados"), hecho que implica la reactivación de los lazos sociales. La esperanza de la proyección cultural hacia el futuro, hacía que se transmitiera de padres a hijos ("echar la bendición los padres a los hijos, poniéndoles la mano en la cabeza y diciéndoles de Dios, seáis benditos”). La cita anterior también se refiere a que se debían rezar las "oraciones que supiesen de dicha Ley", sin importar si son las destinadas para la festividad en cuestión o no. Las plegarias carecían de orden, de consenso, de uniformidad, para tornarse 
individuales ("o lo que cada persona supiese hasta que se cansasen, y se acostasen a dormir").

Entre los criptojudíos se efectuaba la práctica del ayuno según sus condiciones de vida, lo que devino en la transformación del significado sagrado oficial: además de que no seguían el orden del proceso ritual, no contaban con objetos sagrados - como el talit o la misma Torá-, no se reunían mínimo diez varones iniciados para expresar los rezos (minian), no respetaban las fechas ni horarios estipulados en la Letra, etc., lo que los llevó a interpretaciones superficiales y mal entendidas de los preceptos religiosos.

Si el concepto de religión es una relación que tienen todos los miembros de una comunidad en torno a prácticas y creencias cargadas del poder para velar por ella, entonces los criptojudíos reinventaron una seudoreligión tomando como base lo que entendían de las Leyes sagradas. El ayuno se volvió un símbolo del pasado, de lo perdido, de la esperanza de salvación, pero también de trasgresión, de culpa y contradicción, ya que su significado original se fue borrando hasta convertirse en simulacro.

Aun así, la necesidad de no romper con el vínculo entre Dios y los hombres motivaba a las mujeres a transmitir a sus hijos el sentido que entendían del ayuno, no obstante, implicaba una enseñanza peligrosa que podía arriesgar su vida. Isabel Antunez introduce a sus hijos en la Ley de Moisés:

[...] y se acuerda había oído decir a la dicha doña Ysavel Antunez no sólo que hacía algunos ayunos della, sino que se la había enseñado a los dichos sus dos hijos, Manuel y Clara Antunez [...]. (AGNM, I 406, exp. 1, f. 9r.).

Un ejemplo más de la transmisión de los rituales judíos que se llevaba a cabo antes de 1642, se expresa en un testimonio de Isabel de Rivera:

Y que también sabe que sus dos sobrinos, Ra[fael] y Gabriel de Granada, son observantes de la dicha Ley de Moisés, la cual le enseñó su madre doña María de Rivera, como se lo dijeron así ellos como la dicha su madre de esta confesante y por tales observantes se han declarado con esta confesante y ella con ellos, y lo mismo con su madre y hermanas, en cuya conformidad esta confesante le vio hacer un ayuno de la dicha ley al dicho Raphael de Granada y que no sabe qué ayuno era, si del día grande o de los ordinarios, y que al dicho Gabriel, que es el más pequeño, no le ha visto hacer ayuno. Le parece que ha más de un año que le enseñó la dicha ley su madre al dicho Raphael, y poco tiempo después al dicho Gabriel (AGNM, I 406, exp. 1, ff. 169v.-170r.). 


\section{FRONTERAS}

de la historia

Sin embargo, el testimonio implica la presencia de un juez, por lo que el hecho, en lugar de entenderse como un bien ante la expectativa de la trascendencia judía, representa un pecado y, en consecuencia, un hecho que hay que negar. Lo interesante es ver la perspectiva del constructo de verdad que se fomenta: ¿por qué se condena la diferencia?, ¿quién posee la verdad absoluta?

Al ser encarcelados los judaizantes, se polarizaron las actitudes de aceptarse como cristianos o defender su judaísmo. En ambos casos, el sincretismo era marcado, ya que se desajustaron los patrones de comportamiento. Muchas prácticas cristianas se justificaban con elementos del judaísmo:

El hábito carmelita es asimismo considerado como menos impuro que los demás pues, según Margarita de Rivera, "fue de Elías y Eliseo y de los demás profetas de la otra ley": buen ejemplo de la confusión de las dos tradiciones. (Alberro 432).

El caso de Gonzalo Váez es interesante, pues toma la postura de ser firme en su forma de entender el judaísmo, defendiéndose de las presiones y creando complicidades con los presos familiares. Para ello inventó un código que funcionaba para comunicarse en las cárceles, tanto con su hermana Leonor, como con su amiga Ana Gómez. El ayuno era, de nuevo, el tema fundamental de sus diálogos que, de manera creativa, se expresaba en cantos:

[...] Que así quedó el concierto; y Leonor Vaez suspiraba muy recio, con lo cual la debía entender Gonzalo, el cual dijo cantando: "Para, para, que sepas lo que he hecho y haré, soy todo el poder de sufrir, callar y vencer para que con libertad saldré; ha de allá, ha de allá. Hoy [...] también y te diré los baños con velas de amainar, limpiarlos, para purificar, cuando estamos gloriosos al poderoso se lo encomendamos, vuelve a izar de Gavia que nos anegamos y se va a pique la nao, y [...] [ayuno] le hacemos y a él, se los ofrecemos como debemos, a prisa, aprisa, que me aprietan aquí, que me aprietan porque diga, yo no sé, ni diré, [...] maestre de la nao, que me anego en el barco de mi gloria, hay nores [sic] de consuelo [...], aqui la tengo, soy el monarca real, [que] ya todo he de vencer y tu callar, callar, aferra, aferra, todos nos veremos, y allí en nuestra gloria, en paz nos abrazaremos, mira lo que digo maestre y piloto de mi nao, vamos navegando a prisa qué buen viento llevamos; [...] [a ayunar] mañana empezar puedes que yo también lo hago muchas veces y con este viento [...] [ayuno] al puerto de la libertad, la nao nos llevará. Y saldremos callando, qué bueno quita sol para el sereno [...]. (AGNM, I 423, exp. 3, f. 116r.).

El texto revela varios aspectos de la actitud de Gonzalo Váez y su hermana Leonor que nos abren la perspectiva de la condición de los judaizantes en la 
cárcel y de las estrategias con que se valían para mantenerse firmes en sus convicciones. Antes que nada se percibe que los cantos eran un medio para emitir mensajes duales, ya que la música, el ritmo y la mezcla de versos encubrían situaciones ocultas que revelaban actitudes, estados de ánimo, convicciones y motivaciones. Los cantos se expresaban en un diálogo codificado y entendido por los interlocutores: los suspiros de Leonor, por ejemplo, marcaban la respuesta afirmativa de que había entendido el sentido del canto ("Leonor Vaez suspiraba muy recio, con lo cual la debía entender Gonzalo"). Además, se percibe cómo se alentaban ambos para permanecer firmes en su silencio ("Para, para, que sepas lo que he hecho y haré, soy todo el poder de sufrir, callar y vencer para que con libertad saldré; ha de allá, ha de allá") y no ceder a la traición o revelación de lo que saben. En cierta medida, este ocultamiento les proveía un sentido de vida, un motivo que los mantenía con un objetivo concreto que les daba fuerza para soportar la presión. Además, la posesión de la verdad oculta los posicionaba sobre los mismos inquisidores, en el sentido de que éstos querían saber el secreto que ellos encubrían. La palabra, en este sentido, era un elemento de poder que los presos manipulaban tanto para establecer lazos de solidaridad con el prójimo como para mantener su dignidad velando lo que los jueces querían saber.

La temática que se percibe es la del ayuno, como se dijo, y la esperanza de salvación cargada de elementos mesiánicos: "Hoy [...] también y te diré los baños con velas de amainar, limpiarlos, para purificar, cuando estamos gloriosos al poderoso se lo encomendamos, vuelve a izar de Gavia que nos anegamos y se va a pique la nao, y [...] [ayuno] le hacemos y a él, se los ofrecemos como debemos".

En esta mención, también se perciben ciertos elementos del ritual que se tratan de reconstruir, como son los baños previos de purificación requeridos para realizar el ritual o la consagración del sacrificio (ayuno) a Dios. Se observa cómo, en este sentido, los actos corresponden a las creencias, aunque entendidas parcialmente, y proveen un sentido de vida, pues la postura implica una decisión que, por supuesto, desecha otras.

La confianza y los ánimos que se dan los presos se ven reflejados en la siguiente oración: "Soy el monarca real, [que] ya todo he de vencer y tu callar, callar, aferra, aferra, todos nos veremos, y allí en nuestra gloria, en paz nos abrazaremos, mira lo que digo maestre y piloto de mi nao, vamos navegando a prisa qué buen viento llevamos". 


\title{
FRONTERAS
}

de la historia

En este fragmento Gonzalo motiva a Leonor a no hablar, a encubrir la verdad, pues la fe en Dios los llevará a la gloria y a la paz. La metáfora del barco que navega hacia un mundo mejor sirve como imagen de esperanza que los hace verse distanciados de su cárcel. Finalmente, entre figuras retóricas, ritmos y rimas, Gonzalo le avisa a Leonor cuándo es el día en que deben ayunar (“[...] [a ayunar] mañana empezar puedes que yo también lo hago muchas veces y con este viento [...] [ayuno] al puerto de la libertad, la nao nos llevará"). Al respecto, la incertidumbre de cuándo era el día especial del ayuno, también devaluaba, en cierta medida, la festividad, pues no se sabía con exactitud la fecha: "[...] y que se habian de [...] por el mes de septiembre a los diez días de la luna del Lu [nes] del día grande [...]" (AGNM, I 403, exp. 3a, f. 323v.).

Era difícil determinar las fechas del calendario hebreo en el contexto cristiano dominante, más aún sin un guía espiritual que las delimitara. Así, el cálculo era incierto, hipotético, pues recurrían a las estaciones del año para delimitar los días festivos. Es cierto que en los pasajes bíblicos, la mención del Yom Kipur se hace el 10 de tishré (entre septiembre y octubre del calendario gregoriano): "Y os será estatuto perpetuo: En el mes séptimo, el día décimo del mes, afligiréis vuestras almas" (Lev. 16:29). Los criptojudíos novohispanos carecían de referencias temporales correspondientes al calendario lunar hebreo, por lo que suponían la fecha según habladurías o comentarios escuchados entre los semejantes.

Es interesante, además, descifrar en los testimonios las palabras que tienen sentido dual, es decir, codificado para que el referente sea efectivo sólo para ellos. La mención del monosílabo cro significa el ayuno; los sobrenombres que identifican (a la vez que encubren) al individuo (Tristana) juegan también con mensajes ocultos. Esto se comprueba en otro fragmento de los cantos de Leonor con su hermano Gonzalo:

\begin{abstract}
¡Ay, qué es lo que veo!, a la Tristana, a mi marido, a mi padre, madre y abuelos, y me dicen que no diga nada, yo callaré y no diré nada, Tristana, todo lo que he hecho contigo del Cro; me aprieta mucho que lo diga y porque no lo quiero decir me sacaron de tu compañía y me pusieron aquí, antes me ahorcaré que decir palabras, no sé nada que soy buena cristiana. También me aprietan y por eso me ponen aquí, porque diga de mis tíos los Sevilla lo que he hecho con ellos del Cro y lo que me enseñaron del Cro y adónde y cómo lo hice con ellos, qué les importa, yo no sé nada que soy buena cristina (AGNM, I 423, exp.3, f. 256r.).
\end{abstract}

Esta estrategia de comunicarse entre muros era una salida creativa para reafirmar su verdad secreta. Pero había también otras formas de encubrir su 
judaísmo, engañando a las autoridades sobre el ayuno que realizaban. Alberro menciona cómo algunos aprovechaban el ayuno cristiano de la Virgen del Carmen para empalmarlo con el propio y así despistar a los observadores, aunque, como se dijo, creaba inconscientemente confusión entre las dos tradiciones: "[...] se presenta como un auxiliar que facilita la observancia, al disimularla bajo las apariencias del catolicismo" (432).

En ocasiones, por miedo a la represión, decían que se habían abstenido de hacer el ayuno o cualquier otro ritual que fuera sospechoso, es decir, optaban por la eliminación tajante de su pasado y de su identidad:

Y que de la dicha casa se mudaron después, todas, a la calle del Reloj, junto al puente del Carmen, donde vivieron cerca de dos años y esta confesante en esta dicha casa, no hizo ayuno alguno de la dicha Ley de Moisés ni sabe que su madre le hiciese, porque en este tiempo sucedió el haber preso este Santo Oficio a Leonor Nuñez y a sus hijas, y con este miedo y temor, no se atrevían esta confesante y la dicha su madre y hermanas a hablar en cosa de dicha Ley, ni a hacer alguna que le tocase. (AGNM, I 403, exp. 3a, ff. 306v.-307r.).

Como se observa, la negación de la confesante era otra estrategia que pronto se contradecía cuando los jueces y demás integrantes del aparato inquisitorial la confrontaban con otro testimonio. Su propósito, sin embargo, era decir que habían ingerido alimentos el Día Grande para demostrar su indiferencia al judaísmo y su apego al cristianismo, y así, poder ablandar los corazones de los jueces.

Todas estas prácticas de ocultamiento y revelación reflejan la censura del entorno que lleva a los criptojudíos a una cosmovisión particular de percibir su realidad. La consecuencia era la forzosa desviación de las formas rituales, desvirtuando con ello el mismo sentido de la creencia. Así, poco a poco se fueron vaciando los contenidos oficiales, y quedaron sólo las formas domésticas. Ser judaizante era sinónimo de ayunar. El desorden, por tanto, va desmembrando la configuración simbólica, pero al mismo tiempo va construyendo otros referentes que arrastran reminiscencias del anterior.

Se puede reconocer, sin embargo, que cada sociedad interpreta los símbolos oficiales desde sus circunstancias existenciales, ya sea en un marco de censura o de libertad. La diferencia con los judaizantes en la Nueva España era que la represión orientaba sus deducciones, es decir, las opciones se modelaban de acuerdo con la intransigencia del dominador. 


\section{FRONTERAS}

de la fistoria

Vol.12 / 2007

Aunque el ayuno principal y más reiterativo en los testimonios era el del Yom Kipur, también se mencionaban ayunos menores como el de la reina Esther, que recuerda la festividad Purim:

[...] Y que también le enseñó que se habían de hacer tres días de ayuno de la reina Esther, que no se acuerda por qué tiempo le dijo, y que la víspera de ellos se cenaba pescado y legumbres y no carne, y quien pudiese había de estar sin comer, ni beber hasta la última noche del postrer día y que quien no pudiese que ayunase el primero, segundo o tercero día sin comer, ni beber hasta la noche que volvían a cenar pescado y legumbres, y no carne como en la noche del ayuno del día grande, en cuya víspera solamente se bañaban, y no en otros ayunos (AGNM, I 403, exp. 3a, f. 324r.).

Más que recordar el milagro de la reina Esther, que abogó por su pueblo ante el rey de Persia para evitar su exterminio, el testimonio se detiene en cómo había que ayunar: lo que se debía comer y si había de bañarse o no.

En los testimonios inquisitoriales también se mencionan los ayunos realizados para los muertos, llamados en la ortodoxia ta'anit iajid, o penitencia individual, en el que es por propia voluntad realizar el ayuno en cada aniversario del fallecimiento de los padres o algún pariente cercano. En la Nueva España existía la oportunidad de encargar el ayuno a los pobres para que éstos realizaran la penitencia por el alma de otros a cambio de monedas o regalos.

[...] Y que también le enseñó que si quisiesen ayunar por los difuntos de la dicha Ley, lo hiciesen los miércoles, y por los vivos los jueves, y que estos ayuno eran voluntarios, sin más ceremonia que cenar la víspera antes pescado y legumbres y no carne, y lo mismo la noche siguiente sin comer, ni beber en todo el día [...] (AGNM, I 406, exp. 3a, f. 324r.).

Es pertinente detenernos en la interpretación de los días de la semana que Justa Méndez catalogaba para los vivos (jueves) y los muertos (miércoles). Se puede suponer que hay ciertos recuerdos fragmentados de su pasado que arrastraban reminiscencias de prácticas rituales que, junto con la carga hispánica construían una normatividad que daba seguridad. Es probable que la designación de los días referidos tenga que ver con la práctica religiosa oficial de mostrar la Tora a la congregación, lo cual se hace los lunes, los jueves y los sábados. Los otros días permanece oculta, por lo que se aprovechan estos días para los eventos luctuosos. Para esta práctica, también había ciertos alimentos que se identificaban con la muerte, como el huevo duro: 
Y que cuando vino la nueva de que había muerto en Filipinas Manuel de Granada, cuñado de esta confesante, debe de haber dos años, les vino a dar el pésame a esta confesante, su madre y hermanas, doña Michaela Henrriquez, la cual envió a su casa con una negrilla suya a que le trajese unos huevos cocidos duros, los cuales después de haberse traído por la dicha negrita, los repartió la misma doña Michaela entre esta confesante, su madre y hermanas, y su sobrino, Manuel de Granada, por ser ceremonia de la Ley de Moisés que se repartan huevos duros entre los parientes y los coman por mortificación del dolor del difunto o difunta. (AGNM, I 406, exp.1, f. 193r.).

Los rituales de muerte son fundamentales en las prácticas de los judíos, pues justifican, en cierta medida, los cuestionamientos existenciales mediante la promesa de un mundo espiritual, sobrenatural y divino, en el que las almas permanecen ahí hasta la llegada del Mesías. Son muy precisas las reglas que se deben cumplir en los eventos luctuosos; se delimita un orden de secuencias, prácticas y objetos sagrados que hacen efectivo el destino del alma.

En la tradición ortodoxa, durante el duelo, que empieza después de que el cuerpo sea sepultado y la tumba cubierta de tierra (Caro 427), la vida cotidiana se interrumpe durante siete días para todos los afectados más cercanos; el período se prolonga dependiendo de la cercanía de los lazos con el difunto y con el estatus jerárquico del muerto. Así, el ritual judío, según las leyes oficiales, tiene diferentes duraciones: los familiares consanguíneos (los hijos) tienen que guardar medio luto durante un año. Los hombres deben rezar las oraciones matutinas y vespertinas pronunciando, además, la oración de los muertos $(\text { kadish })^{10}$. El cónyuge y demás parientes cercanos no consanguíneos sólo guardan luto durante un mes, en el que también les es prohibido rasurarse o cortarse el cabello o las uñas con tijeras hasta que se cumpla la ceremonia de la cortadura del mes. Durante el año que le sigue a partir de la muerte, los avelim (deudos) naturales seguirán asistiendo al templo cada mañana y cada tarde a rezar las oraciones diarias y las correspondientes a los muertos. Una semana antes de cumplirse un año de la muerte del familiar, los hijos conmemoran la cortadura del año, que es el fin del luto para ellos. A partir de aquí, se

\footnotetext{
${ }^{10}$ El Kadish es una oración muy importante de santificación del nombre de D's en la cual invocamos la revelación de Su gloria en el futuro cercano y la aceptación universal de Su reino. Caro 451. Es interesante observar que aunque se designa como la oración para los muertos, no hay mención de ellos.
} 


\section{FRONTERAS}

de la historia

acostumbra asistir al cementerio en las festividades judías: Rosh Hashaná (Año Nuevo) y Yom Kipur (Día del Perdón) y en cada aniversario de la muerte ${ }^{11}$.

Todas las prácticas y creencias, ya sean las que se derivan de la religión oficial o las de la religión doméstica, marcan el proceso de separación, estado transitorio, y agregación por las que atraviesan el individuo y la comunidad en el ritual luctuoso. Una vez más, el ritual rescata al individuo del desorden material y metafísico, o de condiciones sociales hostiles para acogerlo en su núcleo cultural que encauza la incomprensión hacia una explicación que las justifique y les dé sentido, por supuesto, dentro del marco ideológico del grupo.

Así, Blanca Enrriquez intenta reformular, dentro de su circunstancia de represión, algunas costumbres que recuerda en torno a los ritos mortuorios, específicamente el ingerir huevo duro como símbolo de duelo, a pesar de que la muerte del ser querido sucedió tiempo atrás (dos años antes). Como se observa, los testimonios no sólo expresan la práctica del ayuno como identificador del converso, sino que también hay menciones de otras acciones que tienen que ver con los rituales judíos, es decir, los que atañen a la alimentación y al duelo.

En cuanto a las concepciones sobre la alimentación, es sabido que, desde los parámetros bíblicos, los animales se dividen en impuros y puros, es decir, los prohibidos y los aptos para el consumo. Esta dicotomía también tiene que ver con la delimitación entre lo sagrado y lo pagano, que marca la identidad del grupo en relación con la diferencia.

Las reglas del kashrut ${ }^{12}$ implican un código que, según Mary Douglas, proporciona un conjunto general de posibilidades para significar mensajes particulares ("Deciphering" 249). Si la comida es tratada como código, los mensajes que codifica se encuentran en el modelo de las relaciones sociales. El mensaje se refiere a diferentes grados de sacralidad, a las inclusiones y exclusiones, a los lazos y transacciones a través de los límites. Incluso puede significar estatus social o posiciones de poder. El acto de ingerir comida tiene un componente social y uno biológico. El alimento se carga simbólicamente de acuerdo con distintas categorías concebidas culturalmente que significan según la función que conceptualmente represente:

\footnotetext{
${ }^{11}$ Existen diferentes costumbres, según el lugar, de que las mujeres asistan o no al cementerio. En Salónica, por ejemplo, asistían las mujeres maduras y cercanas al difunto, aunque en el libro del Shuljan Aruj se diga lo contrario.

${ }^{12}$ Del hebreo: bueno, apto para el consumo. Por extensión se aplicó a los alimentos y a los utensilios autorizados en que se preparan.
} 
Meals are ordered in scale of importance and grandeur through the week and the year. The smallest, meanest meal metonymically figures the structure of the grandest, and each unit of the grand meal figures again the wholemeal-or the meanest meal. (Douglas, "Deciphering" 257).

Existen comidas que pertenecen a los días festivos y otras que están dentro del marco cotidiano; hay alimentos que muestran intimidad o amistad, y otros, lejanía (un platillo ligero o sólo el postre). También hay platillos que corresponden a diferentes días de la semana, y algunos que se ingieren a cierta hora del día (desayuno, comida y cena).

El orden está concebido dentro del contexto social y depende de la estructura del grupo que designa lo permitido y lo prohibido (el desorden). Cada comida lleva consigo algún significado que la relaciona con otro alimento significación que se da por contraste o comparación-. Así mismo, cada comida representa un evento dentro de la estructura social que, a su vez, se relaciona con otras prácticas, tanto comunitarias como individuales. La posibilidad de marcar analogías entre las comidas multiplica los significados, que se reafirman mediante la repetición. El nivel de conciencia del mensaje y su significación es, en la mayoría de los casos, obviado por los actos; así, a veces se expresa el grado de la relación desde las conductas que proyectamos al otro, y viceversa. Los símbolos se van dando sentido unos a otros en los diferentes contextos culturales y pueden agruparse mediante la relación de sus significados.

Aplicando las leyes del kashrut — surgidas de la ley mosaica que ha subsistido a lo largo de los siglos - a la concepción simbólica que plantea Mary Douglas, observamos el rechazo y la aceptación de ciertos animales que pueden servir de alimentación. Cada sociedad proyecta en el animal categorías humanas que lo hacen ser deseable o prohibido. Las reglas que categorizan a los animales corresponden a patrones de ideas y comportamientos que gobiernan a las relaciones humanas. Tres son los preceptos bíblicos relacionados con la carne: rechazo de ciertos animales (Lev. 11; Dt. 14), separación de la sangre de la carne antes de cocinarla (Lev. 17:10) y separación tajante de la leche respecto a la carne, que incluye los utensilios para preparar cada uno (Ex. 23:19; Dt. 14:21).

En el primer precepto, que rechaza a ciertas criaturas para su ingestión, los animales están catalogados, antes que nada, desde su nivel de sacralidad: muchos pertenecen a la categoría de "abominables", con la respectiva prohibición de ser tocados o comidos; otros son permitidos para la mesa, pero 


\section{FRONTERAS}

de la historia

no para consagrarlos ante Dios, que son los animales domesticados (no incluye el pescado). La delimitación de unos y otros marca la dicotomía entre lo comestible y lo no comestible, entre lo permitido y lo prohibido, lo puro y lo impuro, lo sagrado y lo profano; así, quien consume los animales prohibidos atenta contra las leyes divinas y se le niega la entrada al templo, además de que está transgrediendo la estructura social misma: fuera de estos márgenes, todo lo demás existe.

De la misma manera en que los israelitas consagraban sus primicias a Dios, incluyendo el primer hijo varón (pidión), también los primeros frutos y animales le eran ofrecidos. Así como los seres humanos cumplen un rol jerárquico en la estructura sociorreligiosa (Cohen, Levy, Israel), los animales se distinguen también unos de otros por su aceptación o rechazo. La analogía que hay entre los humanos y los animales es clara, así como la analogía entre el templo (sagrado) y el ser humano, que debe procurar la pureza para poder acceder a él.

At the level of the individual living beings the purity in question is the purity of the categories. Creeping, swarming, teeming creatures abominably destroy the taxonomic boundaries. At the level of the individual living being impurity is the imperfect, broken, bleeding specimen. The sanctity of cognitive boundaries is made known by valuing the integrity of the physical forms. (Douglas, "Deciphering" 269).

La segunda regla del kashrut — el deber de drenar la sangre del animal antes de cocinarla o consumirla - tiene que ver con la consigna de que "la sangre le pertenece solamente a Dios". Según Douglas, se hace analogía con el mismo esquema dicotómico entre profano y sagrado, cuerpo y templo, bien y mal. La sangre se consagraba a Dios en cuanto que estaba presente en los sacrificios. La carne se transforma simbólicamente de animal viviente en un elemento de consumo alimenticio.

La tercera regla - la separación entre leche y carne - , siguiendo a Douglas, honra la función de procrear. La analogía entre el ser humano y el animal parturiento está siempre implícita, en tanto que la ley (Ex. 23:19 y Talmud 26) prohíbe que el cabrito se cocine en la misma leche de su madre. Esta prohibición fue repetida tres veces en la Tora: una para prohibir comer carne con leche o sus derivados; otra para prohibir el aprovechamiento de esta mezcla, y la tercera para no cocinar estos dos alimentos juntos. 
En conclusión, las leyes marcadas para el kashrut no son del todo lógicas y racionales, sino que pertenecen a una determinada cosmovisión que delimita y estructura las creencias para el mantenimiento de la sociedad. Las leyes funcionan, entonces, para la distinción del grupo respecto a los otros, para el mantenimiento del sistema en cuanto ubica lo permitido y lo prohibido y para moldear el comportamiento de los individuos para la convivencia social. Además, funcionan en el ámbito psicológico como una especie de catarsis en la que se deposita el desprecio y el odio en seres prohibidos e intocables: "It would seem that whenever a people are aware of encroachment and danger, dietary rules controlling what goes into the body would serve as a vivid analogy of the corpus of their cultural categories at risk" (Douglas, "Deciphering" 272).

La interpretación que se percibe entre los criptojudíos se despega, sin embargo, de los parámetros bíblicos debido a la imposibilidad de realizar los procesos tal como lo dictan las leyes sagradas. Las condiciones de censura en el contexto tendían a la homogeneización social: por ello la diferencia representaba una amenaza. Los judaizantes, aunque eran parte de la estructura, permanecían en los márgenes, por lo que representaban un peligro, pues su situación limítrofe los hacía fluctuar entre una postura y otra (la judía y la cristiana). La comida que ingerían en la Nueva España carecía del proceso de preparación estricta del kashrut, pues el animal no se mataba bajo reglas estipuladas, ni se revisaba por personas religiosas encargadas de ello. Además, no se desangraba al animal ni se salaba para el mismo fin. De esta manera, el ritual se limitaba a la privación de ingerir carne de cerdo, como alimento prohibido; no obstante, algunas veces salían a relucir otras reminiscencias extraídas de la ley:

[...] y aunque la dicha Justa Mendez le enseñó que no se había de comer tocino, ni carne, ni manteca de puerco, siempre lo ha comido y usado esta confesante y su madre y hermanas, y nunca hizo esta confesante degollar las aves que comía de temor de las esclavas, ni pus[o] cuidado en eso. (AGNM, I 403, exp. 3a, f. $324 \mathrm{v}$.)

La cita, antes que nada, hace ver la decisión de María de Rivera de negar su tradición, resaltando el haber trasgredido la "Ley de Moisés" ("siempre lo ha comido y usado esta confesante y su madre y hermanas"). Había una jerarquía de valores respecto a los pecados cometidos: comer carne de puerco era una violación menor, no así el ingerir sangre (moronga) o desobedecer la práctica del ayuno principal. Así mismo, se perciben piezas sueltas de un deber ser nostálgico de las leyes del kashrut que definían cómo matar a los animales permitidos, en este caso, a las aves, pues "había [de] degollar las aves con 


\section{FRONTERAS}

de la fistoria

Vol.12 / 2007

cuchillo" (AGNM, I 403, exp. 3a, f. 323v.). La prohibición oficial no especifica la herramienta, sino el evitar el sufrimiento de la víctima, por lo que hay que cortar de determinada manera los conductos sanguíneos para que la muerte sea instantánea. Aunque se puede interpretar este detalle como forma de expresión usada en el contexto, también puede ser que el cuchillo es lo que implica el ritual, desvirtuando el contenido, es decir, aislando la práctica de su espiritualidad.

Es interesante observar cómo la sociedad circundante determina los actos de los judaizantes, en este caso, la mirada de los esclavos ("de temor de las esclavas") que impiden la realización de lo estipulado en la ley. Hay una inversión del poder en este sentido, ya que cualquier manifestación que se relacione con los rituales judíos, podía ser delatada ante los tribunales. Así, el miedo, más que las convicciones, delimitaba las acciones. Los esclavos tenían ciertas referencias, dictados por los edictos expresados en público para conocer a los trasgresores, es decir, había ciertas pautas que debían tener en cuenta para identificar a los conversos dentro de su propia casa, lo que reforzaba el debilitamiento de contenidos religiosos y la prioridad en las formas. La religión se convirtió en un conjunto de prácticas domésticas cargadas de supersticiones y leyendas que distaba de la ortodoxia.

De esta manera, es a partir del "otro" como se modelan los comportamientos. En el caso de la minoría conversa, las formas ajenas se van permeando en sus concepciones de vida y adoptan ciertas creencias cristianas que se vuelven poco a poco parte de sus concepciones ideológicas. El sincretismo va degenerando los principios religiosos; no obstante, luchaban por todos los medios para encontrar una reconfiguración de los valores perdidos. "Confundiendo a los santos con los patriarcas del Antiguo Testamento, Isabel de Medina posee un 'San Moisés' en un guadamecí, objeto de envidia de numerosos judaizantes" (Alberro 433).

La comida era una muestra del rescate de lo propio, pues tenía lugar en el ámbito individual y en el marco de lo cotidiano. Debido a que la religión se desempeñaba en el plano doméstico y, por lo tanto, informal, las adecuaciones de los alimentos típicos del contexto se insertaron en lo que consideraba sagrado. El chocolate, las tortillas, las frutas tropicales, los tamales, los atoles, etc. se cargaban simbólicamente para sustituir la comida ritual, atenuando los ingredientes prohibidos. Hay referencias de que después del ayuno, se ingería chocolate: 
[...] y que un día que esta confesante no estaba en su casa, se había declarado por tal con ella y ella con él y pocos días después que se descubrió, iba de ordinario a visitar a esta confesante y a su madre y hermanas y tres veces, se acuerda, que el dicho Gaspar de Robles, en diferentes días a las seis de la tarde, poco más o menos, le pidió a esta confesante que le diese chocolate y pan, porque estaba en ayunas, sin decirle más palabras, y con esto conoció, evidentemente, esta confesante que aquellos días ayunaba el dicho Gaspar de Robles algunos ayunos de la dicha Ley de Moisés. (AGNM, I 403, exp. 3a, f. 328r.)

O también se sustituía el matzá (pan ácimo), comida ritual de la festividad de Pesaj (Pascua), por la tortilla, ya que ésta no lleva levadura. Estos reemplazos de alimentos transformaban los códigos ortodoxos permitiendo la asimilación y el relajamiento, a veces inconsciente, de la observancia ritual.

Otra adecuación de los alimentos circundantes a las prácticas sagradas era el consumo del pescado, que era accesible en el contexto novohispano. El simbolismo que adquirió tenía que ver con la consideración de que era un manjar que debía utilizarse para las festividades. Pero dentro de las leyes sagradas no era cualquier pescado el que se debía consumir, ya que debía tener escamas y limpiarse según las leyes del kashrut, restricción que no siempre estaba especificada en las declaraciones de los judaizantes:

[...] ensalada, pescado frito, y unos huevos guisados, y algún dulce y no carne y no se acuer[da], distintamente, si el día del dicho ayuno del día grande era día de carne o de pescado; pero aunque fuera día de carne, no la comieran, sino pescado y legumbres, por ser ceremonia de la dicha Ley en el dicho ayuno; y así mismo solía acostumbrar la dicha doña Juana (aunque fuese día de carne) cenar pescado y huevos, y otras cosas por más regalo que la carne, lo cual sabe esta confesante porque cenó con ella muchas veces. (AGNM, I 403, exp. 3a, f. 326v.)

Es interesante detenernos en la perspectiva simbólica que implica el pescado en relación con la carne, ya que ésta constituía un alimento cotidiano, considerado trivial y convencional, a diferencia del primero. La dualidad vuelve a aparecer en la valoración de la comida, en cuanto el pescado se relacionaba con los rituales, por lo que entraba en el mismo campo semántico de lo sagrado; no obstante, la carne debía de ingerirse bajo ciertas normas que, en la Nueva España, no se observaban. Comer pescado implicaba, en consecuencia, el día festivo y, por lo tanto, identificador de los judaizantes. 


\section{FRONTERAS}

de la historia

Otro indicador relevante para reconocer a los judaizantes era el de cuidar el sábado (shabat). En la tradición ortodoxa es el día de descanso semanal en el cual está prohibido realizar cualquier trabajo. En la Tora se menciona: "Y los hijos de Israel guardarán el sábado, observándolo en todas sus generaciones, por pacto perpetuo. Entre Mí y los hijos de Israel ésta es una señal perpetua; porque en seis días hizo el Eterno los cielos y la tierra, mas en el séptimo día descansó y reposó" (Ex. 31:16-17).

Como rasgo que caracteriza el festejo se encienden dos velas antes de caer la noche del viernes, aspecto que se trata de reproducir en el contexto de la Nueva España. El shabat contiene dos principios: descanso y santidad, pues el ser humano brinda reposo, tanto a su cuerpo como a su alma. Cada semana se renueva la declaración de la fe en Dios. Concebida como una festividad importante, se acostumbra bañarse y usar ropa festiva, se anticipa la preparación de la comida para no tener que trabajar el sábado, se bendice el vino, se prepara el pan ritual y se dispone la mesa en honor de la celebración, todo ello para consagrarlo a Dios. En la víspera del shabat y en la mañana del día siguiente se reúnen en la sinagoga para realizar las plegarias correspondientes: salmos (sobre todo el 92) y poemas litúrgicos. Las restricciones están detalladamente especificadas, como no trasladar objetos de un lugar a otro, no cortar, no pegar, no encender lumbre, etc., todas estipuladas a lo largo de la Tora, el Talmud o el Shuljan Aruj, libros sagrados todos.

Justa Méndez transmite el mensaje de que "se habia de guardar los sábados por dias de fiesta" (AGNM, I 403, exp. 3a, f. 323v.), pero las confusiones, tanto de contenidos espirituales como de formas, degeneraron en respuestas espontáneas formando una religiosidad desviada. La inercia con que cada vez más dejaban sus creencias para apropiarse de las ajenas, derivó en la tergiversación de los conceptos. Así, en el contexto novohispano se jerarquizaron las festividades rituales: la más importante era el Yom Kipur y, de ahí, las demás pasaron a un nivel inferior e individual, pues cada quien las asumía a su entender. Un factor que determinó la anulación de la celebración del shabat fue la condición de pobreza, que instó a algunos judaizantes a abandonar la práctica: " [...] el ponerse ropa limpia en ellos, y en los sábados, lo hacía cuando la tenía, y que muchos sábados y así todos, trabajaba para gana[r] de comer" (AGNM, I 403, exp. 3a, f. 324v.).

La limpieza de la casa y del cuerpo eran referentes que identificaban a la festividad de shabat, pues era un requerimiento de preparación: “[...] y que los viernes en la tarde y las vísperas del ayuno del día grande se habían de barrer y 
limpiar las casas en observancia de los sábados [...]" (AGNM, I 403, exp. 3a, f. 324r.).

Las limitaciones que están declaradas en la Tora y explicadas e interpretadas en el Talmud, el Shul'ján Aruj, la Cábala y demás textos oficialmente sagrados, exigen precisión y dedicación de los creyentes para cumplir adecuadamente con los rituales, tanto cotidianos, como los que corresponden al ciclo de vida y al ciclo anual, que implican las festividades mayores. Así, las prácticas están aliadas a parámetros espirituales, ya que se supone que es el mismo Ser Supremo el que dicta las leyes a Moisés. El shabat fue santificado desde el día de la creación, por lo que es un día dedicado a Dios.

De esta manera, las prácticas aparentes encubrían un desfase ideológico donde el individuo experimentaba una incongruencia entre los constructos impuestos por el entorno y los propios. Ante este desajuste que experimentaron los conversos, se vieron en la necesidad de buscar una salida a su represión, que no siempre fue la adecuada. La escisión entre lo aparente y lo oculto los sumió en cuestionamientos, revaloraciones y conflictos existenciales que se manifestaron en varias actitudes: de negación, de solidaridad, de esperanza, de proselitismo, etc., todas ellas envueltas por el sentimiento del miedo que las disparaba hacia direcciones diversas. Lo cierto es que la desintegración de la identidad en torno al reconocimiento mutuo fue inminente. La alternativa entre la pérdida de sus creencias para asimilarse a la idiosincrasia cristiana dominante, o asumir el rechazo social para permanecer ligados a su legado ancestral, fueron posturas que no siempre se cumplieron, pues ninguna de las dos opciones eran contundentes: más bien, se presentó el sincretismo en el que la ambigüedad en torno a la pertenencia los hacía reinventar prácticas confusas que no seguían ni la ortodoxia cristiana ni la judía. Los intentos desesperados por mantener la memoria de la observancia mosaica mostraban una resistencia que, ante el miedo y el sometimiento inquisitorial, resultaba no ser del todo firme. En este sentido, el determinismo que impuso el entorno novohispano fue mayor que la voluntad del individuo. "En Nueva España no fue avivada la llama mosaica y los seres humanos fueron desapareciendo uno tras uno, llevándose consigo el tenue mensaje que no habían podido transmitir" (Alberro 454).

En el momento en que se registraron los testimonios en los archivos inquisitoriales, algunos individuos todavía tenían asomos de recuperar su fe; otros más bien optaron por la asimilación, negando su origen para ser perdonados y salvar su vida. Así, los primeros, tenían la necesidad de mantener la conciencia colectiva que definiera su diferenciación identitaria basada en los 


\section{FRONTERAS}

de la historia

parámetros religiosos, lo que hizo que acudieran a su memoria para reformular sus creencias, que resultaron ser rasgos mal entendidos, pastiches de recuerdos que configuraron una idea turbia de la religión institucional. Los que tomaron la actitud de la asimilación ideológica acusaron a sus semejantes resaltando prácticas rituales que habían desempeñado en el pasado. Ambas posturas provocaron el surgimiento de indicadores sueltos que eran tomados en cuenta por los observadores externos. De esta manera, se fueron delimitando identificadores religiosos y sociales que no sólo se manifestaron desde afuera, sino que también los judaizantes los utilizaban tanto para sus prácticas internas, como para la delación de su prójimo. En este punto, vemos una distancia temporal que mediaba entre la configuración social antes de 1642 y después, cuando se intensificó la persecución a los conversos y se produjo el desmembramiento de la comunidad; no obstante, algunos se aferraban a dichas pautas identitarias aún dentro de las cárceles.

Las dinámicas sociales se alteraron ante estos señalamientos, tanto desde el interior del grupo como desde la mirada exterior de los delatores posicionados como observadores, con cierta distancia respecto a sus víctimas. Los judaizantes trataban de negar, minimizar o camuflar sus actos comprometedores durante sus confesiones, tratando de encubrir sus faltas. Los jueces, por su parte, intentaban detectar contradicciones, mentiras y provocar relaciones con otros testimonios, motivados por dichos indicadores.

Es interesante resaltar que en los testimonios la reiteración de la mención del ayuno del Día Grande, por ejemplo, muestra la carga simbólica que se le daba al ritual, pues más que respetar el orden y el desempeño de la ortodoxia, resaltaba el sentido de redención, de la expiación de sus culpas. Los indicadores, por tanto, desarticularon el significado oficial transformando con ello la cosmovisión del individuo ante su mundo. La identificación de ciertas prácticas selectas tendió a estereotipar a los culpables, perdiendo de vista la consigna inicial, ya de por sí incoherente, pues se inculpaba por el origen. El ayuno ritual resultaba aislado, es decir, se utilizaba como herramienta para diferenciar el bien del mal, concebido de manera inversa desde los sujetos que lo practicaban y desde la concepción de la autoridad, inmersa en la estructura eclesiástica dominante que dirigía el eje del poder político, social e ideológico. El ayuno del Día Grande y otros indicadores menores - como las prácticas alimenticias (comer cerdo o sangre, matar de cierta forma al animal o comer pescado), barrer y limpiar la casa o trabajar en shabat o bañarse y usar ropa limpia - resultaban detonadores que bipolarizaban a la sociedad novohispana diferenciando a los herejes de los auténticos cristianos viejos. De esta manera, las actividades 
cotidianas, propias de cualquier ser humano (comer o asearse), resultaban sospechosas, motivos de censura, interpretados desde la perspectiva de la autoridad, que no eran sólo los inquisidores, sino también la sociedad cristiana mayoritaria que funcionaba como medio de control, al detectar comportamientos heterodoxos y referirlos al Santo Oficio.

Ante la exposición de dichas acciones inculpadoras, los judaizantes se vieron envueltos en incertidumbres, pues la desestabilización del marco de referencia rompió con la confianza y la solidaridad que posibilitaba el capital social. La desconfianza en el prójimo hizo que constantemente se pusiera a prueba la fidelidad o la traición, posturas individuales, más que consensuales. Sin embargo, ni la asimilación ni el rechazo produjeron una respuesta coherente respecto a su situación.

De esta manera, los creyentes novohispanos de la Ley de Moisés fueron desapareciendo poco a poco de la escena colonial, sin poder reproducir su legado cultural milenario. La asimilación, a pesar de la resistencia de algunos, fue inminente y sólo quedaron restos de prejuicios irracionales que se han arrastrado hasta nuestros tiempos.

\section{Bibliografía}

\section{Fuentes primarias}

Archivo General de la Nación, México (AGNM).

Inquisición (I) 403, 406, 423.

\section{Fuentes secundarias}

Alberro, Solange. Inquisición y sociedad en México 1571-1700. 1988. México: Fondo de Cultura Económica, 2004.

Bel Bravo, María Antonia, coord. Diáspora sefaradí. Madrid: Mapfre, 1992.

Biblia Humash ha-mercaz. Libro de la Torah. Buenos Aires: Centro Educativo Sefaradí de Jerusalem, 1970. 


\section{FRONTERAS}

de la historia

Caro, Joseph. Shul'han Aruj. Recopilación de las leyes prácticas según la tradición sefaradí. Recop. Abraham M. Hassan. México: Jerusalem de México, s. f.

Douglas, Mary. Pureza y peligro. Un análisis de los conceptos de contaminación y tabú. 1966. Madrid: Siglo XXI, 1973.

- "Deciphering a Meal". Implicit Meanings. Essay in Anthropology, Douglas Mary. Londres; Boston: Routledge; Kegan Paul, 1975. 249-75.

Gojman Goldberg, Alice. Los conversos en la Nueva España. México: Universidad Nacional Autónoma de México; ENEP; Acatlán. s. f.

Ferry, Robert J. "Margarita Moreira: amores, amistades, y los grupos de criptojudíos portugueses en México, siglo XVII". III Jornada de Estudios de Historia de las sensibilidades 6 (2006). Revista en línea. Consultado: 6 de agosto de 2007, <http//nuevomundo.revues.org/document 2043.html>.

Hamui Sutton, Silvia. "Simbología poética y visión del mundo en los cantos judeo-españoles". Trabajo de grado de doctorado. Universidad Nacional Autónoma de México, 2006.

Kaplan, Yosef. "Los sefaradíes en Europa”. Diáspora Sefaradí. Coord. María Antonia Bel Bravo. Madrid: Mapfre, 1992.

Masera, Mariana. "Literatura y canción popular en los cantares de presos en las cárceles de la Inquisición". La otra Nueva España. La palabra marginada en la Colonia. Coord. Mariana Masera. Barcelona: Azul; Universidad Nacional Autónoma de México, 2002.

Rubial García, Antonio. Profetisas y solitarios. México: Universidad Nacional Autónoma de México; Fondo de Cultura Económica, 2006.

Sacristán, María Cristina. Locura e inquisición en la Nueva España 1571-1760. México: El Colegio de Michoacán; Fondo de Cultura Económica, 1992.

Sarrión Mora, Adelina. Beatas y endemoniadas. Mujeres heterodoxas ante la Inquisición, siglos XVI a XIX. Madrid: Alianza, 2003. 
Wachtel, Nathan. La fe del recuerdo. Laberintos marranos. Buenos Aires: Fondo de Cultura Económica, 2007.

Fecha de recepción: 28 de febrero de 2007.

Fecha de aprobación: 30 de julio de 2007. 